ISSN: 2302-8556

E-Jurnal Akuntansi Universitas Udayana

Vol.24.3.September (2018): 1687-1708

DOI: https://doi.org/10.24843/EJA.2018.v24.i03.p02

\title{
Pengaruh Struktur Kepemilikan Terhadap Price Book Value (PBV) dengan Manajemen Laba Sebagai Variabel Intervening
}

\author{
Kartika Widya Tri Dewanti ${ }^{1}$ \\ I Gusti Ngurah Agung Suaryana ${ }^{2}$ \\ ${ }^{1}$ Fakultas Ekonomi dan Bisnis Universitas Udayana (Unud), Bali, Indonesia
email: widyatdk@ gmail.com / Telp: +6281236860066
${ }^{2}$ Fakultas Ekonomi dan Bisnis Universitas Udayana (Unud), Bali, Indonesia
}

\begin{abstract}
ABSTRAK
Tujuan dari penelitian ini yaitu untuk menguji adanya pengaruh struktur kepemilikan yang terdiri dari kepemilikan institusional dan kepemilikan manajerial terhadap price to book value ratio (PBV) dengan manajemen laba sebagai variable intervening. Sampel penelitian didapat sebanyak 34 perusahaan manufaktur yang telah diseleksi menggunakan metode purposive sampling dari populasinya sebanyak 139 perusahaan yang terdaftar di Bursa Efek Indonesia (BEI) secara berturut-turut selama periode 2014-2016. Analisis statistik deskriptif, uji asumsi klasik dan analisis path merupakan teknik analisis yang digunakan dalam penelitian ini.Pengujian dari penelitian ini menunjukkan hasil bahwa kepemilikan institusional dan kepemilikan manajerial berpengaruh negatif terhadap PBV, kepemilikan institusional dan kepemilikan manajerial tidak berpengaruh terhadap manajemen laba, manajemen laba berpengaruh positif terhadap PBV, manajemen laba bukan merupakan variabel intervening dalam pengaruh kepemilikan institusional dan kepemilikan manajerial terhadap PBV.

Kata kunci : kepemilikan institusional, kepemilikan manajerial, manajemen laba, price to book value ratio $(\mathrm{PBV})$
\end{abstract}

\begin{abstract}
The purpose of this research is to examine the impact of ownership structure consisting of institutional and managerial ownership to price to book value ratio $(P B V)$ with earnings management as intervening variable. The samples of this research are 34 manufacturing companies that have been selected using purposive sampling method from their population of 139 companies listed in Indonesia Stock Exchange (IDX) during 2014-2016 period consecutively. Descriptive statistical analysis, classical assumption test and path analysis is analyticals technique used in this research.The examination of this research shows that the result of institutional and managerial ownership negatively affect on $P B V$, institutional and managerial ownership have no impact on earnings management, earnings management have positive effect on $P B V$, earnings management is not an intervening variable in the impact of institutional and managerial ownership on PBV.

Keywords : institutional ownership, managerial ownership, earnings management, price to book value ratio $(P B V)$
\end{abstract}


Kartika Widya Tri Dewanti dan I Gst Ngurah Agung Suaryana, Pengaruh...

\section{PENDAHULUAN}

Era perekonomian modern ini, pasar modal merupakan salah satu alternatif dalam pengembangan perekonomian di suatu negara. Adanya pasar modal, mobilisasi dana dapat tersalurkan dengan tepat baik dalam negeri maupun luar negeri. Investasi yang diminati oleh pasa investor adalah saham dari perusahaan yang telah go public.

Pasar modal merupakan cerminan diri tentang kondisi keuangan dan kinerja perusahaan. Peningkatan harga saham merupakan respon positif pasar ketika kondisi keuangan dan kinerja perusahaan baik.

Investor memerlukan informasi tentang penilaian saham untuk pengambilan keputusan investasi. Price to book valueratio(PBV) adalah salah satu indikator nilai saham yang banyak digunakan investor untuk mengetahui nilai wajar saham. PBV atau rasio nilai pasar tersebut digunakan dalam menilai bagaimana pasar menghargai nilai buku saham suatu perusahaan.

Upaya pemegang saham atau pemilik (principal) untuk memaksimalkan kesejahteraannya yaitu dengan menyerahkan pengelolaan perusahaan kepada tenaga ahli atau professional yang disebut manajer (agent). Kewajiban manajer tersebut harus mempertanggungjawabkan semua pekerjaannya kepada pemegang saham. Disinilah konflik kepentingan terjadi. Pihak manajemen atau manajer sering mempunyai kepentingan yang bertentangan dengan tujuan utama perusahaan. Konflik kepentingan antara manajer dan pemegang saham sering disebut konflik keagenan (Jensen dan Meckling, 1976). Manajer cenderung bertindak untuk kepentingan 
ISSN: 2302-8556

E-Jurnal Akuntansi Universitas Udayana

Vol.24.3.September (2018): 1687-1708

pribadi, bukan untuk kepentingan perusahaan. Hal inilah yang menyebabkan munculnya biaya keagenan (agency cost).

Biaya keagenan dapat dikurangi dengan beberapa alternatif, yaitu alternatif pertama yaitu menyertakan manajemen sebagai pemilik. Manajer yang memiliki sebagian besar ekuitas di perusahaan memiliki insentif yang lebih rendah untuk memanipulasi informasi akuntansi yang dilaporkan (Alves, 2012). Alternatif selanjutnya adalah dengan meningkatkan kepemilikan institusional sebagai agen pengawasan.

Pengawasan terhadap kinerja manajemen akan lebih optimal dengan adanya kepemilikan institusional (Islamiya dan Amanah, 2016). Kinerja perusahaan yang meningkat akan berdampak pada peningkatan harga saham yang menyebabkan PBV meningkat juga.

Beberapa penelitian mengenai pengaruh struktur kepemilikan padanilai perusahaan, struktur kepemilikan pada manajemen laba dan manajemen laba pada nilai perusahaan, dengan nilai perusahaan diukur menggunakan PBV. Terdapat ketidakkonsistenan terhadap hasil penelitian sebelumnya, seperti Pasaribu dkk., (2016) dan Apriada dan Suardhika (2016) menyatakan bahwa kepemilikan institusional dan kepemilikan manajerial berpengaruh positif dan signifikan terhadap nilai perusahaan.

Teori keagenan menjelaskan adanya kontrak kerjasama antara principal (pemilik perusahaan) dan agent (manajemen perusahaan) dimana 
Kartika Widya Tri Dewanti dan I Gst Ngurah Agung Suaryana, Pengaruh...

principalmenyerahkan pengelolaan perusahaan kepada agent. Manajemen adalah pihak yang dikontrak oleh pemegang saham untuk bekerja kepadanya. Sebagian wewenang manajemen adalah membuat keputusan bagi kepentingan pemegang saham.Asumsi utama dari teori keagenan adalah tentang tujuan principal dan tujuan agent yang berbeda. Tujuan yang berbeda tersebut yang menimbulkan konflik karena agent cenderung mengejar tujuan pribadi.

Brigham dan Hauston (31:2006) menyatakan bahwa sinyal merupakan tindakan perusahaan bagi investor untuk memberikan petunjuk tentang prospek perusahaan mendatang. Asimetri informasi menyebabkan adanya dorongan pemberian sinyal kepada pihak eksternal, dimana perusahaan lebih mengetahuiinformasi tentang perusahaan dan prospek kedepan. Kurangya informasi bagi pihak luar menyebabkan adanya perlindungan diri dengan pemberian harga rendah untuk perusahaan. Teori sinyal juga dapat membantu agent, principal, dan pihak luar perusahaan mengurangi asimetri informasi dengan menghasilkan laporan keuangan yang berkualitas.

Watts and Zimmerman (1986) memeloporitentang Positive Accounting Theory (PAT), dimana pembuat laporan keuangan atau perilaku manajer dipengaruhi oleh beberapa faktor tertentu.Tiga hipotesis dalam PAT menurut Watts and Zimmerman (1986), yaitu (1) hiposesis rencana bonus (bonus plan hypothesis), dimana manajer pada perusahaan yang memiliki rencana bonus, akan lebih menyukai meningkatkan laba periode berjalan dengan menggeser laba pada periode yang akan datang ke periode saat ini. Hal tersebut dilakukan dengan harapan manajer dapat memperoleh 
ISSN: 2302-8556

E-Jurnal Akuntansi Universitas Udayana

Vol.24.3.September (2018): 1687-1708

bonus maksimal setiap tahunnya, karena besarnya tingkat laba yang diperoleh perusahaan merupakan ukuran keberhasilan kinerja manajer, (2) hipotesis hutang/ekuitas (debt/equity hypothesis), dimana manajer pada perusahaan yang mempunyai debt to equity ratio tinggi, memiliki kemungkinan lebih besar untuk memilih metode akuntansi yang dapat menaikan laba agar terhindar dari pelanggaran perjanjian utang. Alasannya bahwa laba bersih yang dilaporkan naik akan mengurangi probabilitas kegagalan membayar utang-utangnya dimasa mendatang (Scott, 2006:353). Kenaikan laba perusahaan akan menarik perhatian kreditor untuk memberikan tambahan pinjaman, (3) hipotesi biaya politik (political cost hypothesis), dimana perusahaan besar dengan tingkat laba yang tinggi banyak dijadikan obyek implementasi peraturan maupun kebijakan pemerintah yang mengakibatkan tingginya biaya politik. Scott (2006:303) menyatakan bahwa untuk meminimalisir biaya politik, suatu perusahaan akan cenderung melalukan rekayasa menurunkan labanya.

Sebelum memutuskan untuk berinvestasi, investor sering mengacu padaPBV yaitu dengan membandingkan harga pasar saham dengan nilai bukunya. Tingginya PBV merupakan cerminan dari tingginya harga saham dibandingkan nilai bukunya. Perusahaan akan semakin berhasil memakmurkan pemegang saham ketika harga saham semakin tinggi.

Kepemilikan institusional merupakan proporsi pemegang saham oleh pihak institusi seperti perusahaan asuransi, bank, perusahaan investasi dan kepemilikan saham lainnya (Rasyid, 2015). Institusi tersebut merupakan pihak berkemampuan 
Kartika Widya Tri Dewanti dan I Gst Ngurah Agung Suaryana, Pengaruh...

professional dalam menetapkan baik buruknya kinerja perusahaan serta dalam membuat keputusan. Kepemilikan institusional yang tinggi mengakibatkan semakin tingginya dorongan pihak institusi untuk mengawasi manajemen dari perilaku opportunisticdan berakibat pada terdorongnya pihak manajemen untuk mengoptimalkan kinerja perusahaan.

Kepemilikan manajerial adalah proporsi pemegang saham oleh direktur, manajemen, komisaris dan pihak lainnya yang berperan aktif dalam pengambilan keputusan (Rasyid, 2015). Konflik keagenan antara investor dan pihak manajemen dapat berkurang jika dalam struktur kepemilikan saham perusahaan tersebut terdapat kepemilikan saham oleh pihak manajer, dengan kata lain manajer tersebut sekaligus sebagai pemegang saham. Kepemilikan saham oleh pihak manajerial mempengaruhi kinerja manajemen dalam mengoptimalkan perusahaan, karena kepemilikan manajerial dapat membantu menyatukan perbedaan kepentingan antara kedua belah pihak yaitu investor dan manajer. Manfaat dan kerugian langsung akan dirasakan manajer ketika ia berhasil atau salah atas keputusan yang diambil.

Penurunan dan peningkatan laba perusahaan yang disebut manajemen laba merupakan tindakan manajer guna melindungi diri mereka dan perusahaan dalam mengantisipasi kejadian tidak terduga yang dapat mempengaruhi nilai pasar perusahaan. Scott (2006:383) membagi pola manajemen laba manjadiempat yaitu taking a bath, income minimization, income maximization dan income smoothing. 
ISSN: 2302-8556

E-Jurnal Akuntansi Universitas Udayana

Vol.24.3.September (2018): 1687-1708

Pihak institusi bertugas untuk memonitor kegiatan manajemen dalam mengelola perusahaan. Teori keagenen menyatakan bahwa semakin besar kepemilikan institusional, maka pengawasan terhadap manajemen akan menjadi lebih baik dan ketat sehingga dapat mengurangi tindakan opportunistic manajer yang dapat merugikan perusahaan. Pasaribu dkk., (2016) dan Apriada dan Suardhika (2016) menyatakan bahwa struktur kepemilikan institusional berpengaruh positif dan signifikan terhadap nilai perusahaan yang dihitung dengan rasio PBV.

$\mathrm{H}_{1}$ : Struktur kepemilikan institusional berpengaruh positif signifikan terhadap PBV

Kepemilikan manajerial merupakan kepemilikan saham oleh pihak manajer, dengan kata lain manajer tidak hanya sebagai pihak eksternal yang digaji untuk mencapai tujuan perusahaan, melainkan juga sebagai pemilik perusahaan. Kepemilikan manajerial merupakan alat monitoring internal yang penting untuk memecahkan konflik agensi antara external stockholders dan manajemen(Chen dan Steiner, 1999).Kadarusman (2012) mengatakan bahwa struktur kepemilikan manajerial berpengaruh postitif dan signifikan terhadap nilai perusahaan yang dihitung dengan rasio PBV.

$\mathrm{H}_{2}$ : Struktur kepemilikan manajerial berpengaruh positif signifikan terhadap PBV. Kepemilikan saham oleh institusi memiliki kemampuan untuk memantau tindakan manajer secara efektif sehingga dapat mengurangi praktik manajemen laba. Hal tersebut akan menurunkan kemampuan manajer untuk mengelola laba akuntansi 
Kartika Widya Tri Dewanti dan I Gst Ngurah Agung Suaryana, Pengaruh...

perusahaan karena pihak investor institusi dianggap sebagai sophisticated investor yang tidak mudah dibodohi oleh manajer karena mereka adalah investor yang tidak hanya menerima, namun canggih dalam menganalisis dan menginterpretasikan informasi yang diterimanya, sehingga manajer akan lebih fokus dalam meningkatkan kinerja perusahaan. Hartanto dan Nugrahanti (2012) menyatakan bahwa kepemilikan institusional berpengaruh negatif dan signifikan pada manajemen laba. Adanya kepemilikan institusional yang tinggi dapat membatasi perilaku manajer untuk mengelola laba.

$\mathrm{H}_{3}$ : Struktur kepemilikan institusional berpengaruh negatif signifikan terhadap manajemenlaba.

Adanya kepemilikan manajerialmendorong manajer untuk dapat memaksimalkan nilai perusahaan, karena manajer memiliki proporsi kekayaan sebagai pemegang saham. Hal tersebut dapat mengurangi konflik keagenen sehingga kemakmuran pemegang saham dan kinerja perusahaan akan ditingkatkan oleh manajer, karena memakmurkan pemegang saham sama dengan memakmurkan dirinya sendiri. Putri dan Yuyetta (2013)menyatakan bahwa struktur kepemilikan manajerial berpengaruh negatif dan signifikan terhadap manajemen laba dengan manajemen laba diukur dengan discretionary accruals.

$\mathrm{H}_{4}$ : Struktur kepemilikan manajerial berpengaruh negatif signifikan terhadap manajemen laba.

Asimetri informasi antara manajer dan pemilik menyebabkan manajer lebih mempunyai informasi internal lebih banyak dibandingkan pemilik, sehingga adanya 
ISSN: 2302-8556

E-Jurnal Akuntansi Universitas Udayana

Vol.24.3.September (2018): 1687-1708

kesempatan manajer untuk melakukan manajemen laba. Manajemen laba yang dilakukan terlalu tinggi merupakan hal yang tidak wajar karena laba yang dilaporkan menjadi semu dan menyesatkan pengguna informasi. Rendahnya kualitas laba yang dilaporkan akan berdampak pada salahnya pengambilan keputusan oleh pemakai laporan keuangan dan mengakibatkan nilai perusahaan berkurang (Siallagan dan Machfoeds, 2006).

$\mathrm{H}_{5}$ : Manajemen laba berpengaruh negatif signifikan terhadap PBV.

Hipotesis yang dirumuskan sebelumnya telah menjelaskan tentang hubungan parsial antara variabel struktur kepemilikan institusional terhadap manajemen laba, struktur kepemilikan institusional terhadap PBV, serta manajemen laba terhadap PBV. Adanya kepemilikan oleh institusi sebagai pihak yang dapat memonitor perilaku manajer sehingga manajer akan berusaha untuk meningkatkan kinerjanya sehingga dapat menyebabkan meningkatnya harga saham yang berpengaruh pada peningkatan PBV.

$\mathrm{H}_{6}$ : manajemen laba sebagai variabel intervening pengaruh struktur kepemilikan institusional terhadap PBV.

Hipotesis yang dirumuskan sebelumnya telah menjelaskan tentang hubungan parsial antara variabel struktur kepemilikan manajerial terhadap manajemen laba,struktur kepemilikan manajerial terhadap PBV, serta manajemen laba terhadap PBV. Kecilnya jumlah kepemilikan saham manajerial menyebabkan manajer lebih mementingkan tujuannya sebagai seorang manajer daripada sebagai pemegang saham, dan dapat menyebabkan nilai perusahaan turun. Hal ini dikarenakan 
Kartika Widya Tri Dewanti dan I Gst Ngurah Agung Suaryana, Pengaruh...

perusahaan harus menaggung biaya monitoring dan menyediakan bonus bagi manajer.

$\mathrm{H}_{7}$ : manajemen laba sebagai variabel intervening pengaruh struktur kepemilikan manajerial terhadap PBV.

\section{METODE PENELITIAN}

Perusahaan yang menjadi populasi adalah 139 perusahaan manufaktur yang telah terdaftar di Bursa Efek Indonesia pada tahun 2014-2016, yang kemudian diseleksi mengggunakan metode purposive samplingdengan kriteria yang telah sehingga diperoleh sampel yang dapat mewakili populasi yang ada sesuai tujuan penelitian.sehingga didapat 34 perusahaan selama 3 tahun pengamatan, sehingga sampel yang didapat adalah 102 observasi.

Rasio price to book value umunya lebih dari satu, yang mencerminkan bahwa nilai pasar saham lebih besar dari nilai bukunya.

$$
\mathrm{PBV}=\frac{\text { harga pasar saham per lembar }}{\text { nilai buku saham per lembar }} \mathrm{X} 100 \% \ldots \ldots \ldots \ldots \ldots \ldots \ldots \ldots \ldots \ldots \ldots \ldots
$$

Struktur kepemilkan institusional adalah proporsi kepemilikan oleh pihak institusi.

$$
\mathrm{KI}=\frac{\text { Kepemilikan saham oleh institusi }}{\text { Total keseluruhan saham perusahaan }} \mathrm{X} 100 \%
$$

Struktur kepemilikan manajerial adalah proporsi kepemilikan oleh pihak manajer.

$$
\mathrm{KM}=\frac{\text { Kepemilikan saham oleh manajer }}{\text { Total keseluruhan saham perusahaan }} \mathrm{X} 100 \%
$$


ISSN: 2302-8556

E-Jurnal Akuntansi Universitas Udayana

Vol.24.3.September (2018): 1687-1708

Manajemen laba dihitung dengan menggunakan ModifiedJones Model yang merupakan perkembangan dari model Jones (Dechow, 1995). Model perhitungannya sebagai berikut:

$\mathrm{DA}_{\mathrm{it}}=\mathrm{TA}_{\mathrm{it}}-\mathrm{NDA}_{\mathrm{it}}$

Keterangan :

$\mathrm{DA}_{\text {it }}$ : discretionary accuruals perusahaan i pada periode $\mathrm{t}$

$\mathrm{TA}_{\mathrm{it}}$ : total akrual perusahaan i pada periode $\mathrm{t}$

$\mathrm{NDA}_{\text {it }}$ : nondiscretionary accuruals perusahaan I pada periode $\mathrm{t}$

\section{HASIL DAN PEMBAHASAN}

Berdasarkan Tabel 1., diketahui bahwa variabel kepemilikan institusional mempunyai nilai minimum sebesar 0,019640 dan nilai maksimum sebesar 0,980010. Rata-rata kepemilikan institusional adalah sebesar 0,67760618 atau 67,76\% dengan standar deviasi (simpanga baku) sebesar 0,172192325.

Tabel 1.

Hasil Statistik Deskriptif

\begin{tabular}{cccccc}
\hline & N & Minimum & Maximum & Mean & Std. Deviation \\
\hline KI & 102 & 0,019640 & 0,980010 & 0,67760618 & 0,172192325 \\
KM & 102 & 0,000000 & 0,894440 & 0,06904020 & 0,133107582 \\
ML & 102 & $-0,100090$ & 0,122070 & $-0,00070716$ & 0,042342376 \\
PBV & 102 & 0,119690 & $2,716,670$ & $102,370,873$ & 0,640489976 \\
$\begin{array}{c}\text { Valid N } \\
\text { (listwise) }\end{array}$ & 102 & & & & \\
\multicolumn{7}{l}{ Sumber $:$ Data diolah, 2017} & & &
\end{tabular}

Variabel kepemilikan manajerial mempunyai nilai minimum sebesar 0,000000 dan nilai maksimum sebesar 0,894444. Mean Kepemilikan manajerial 0,06904020 dengan standar deviasi (simpangan baku) sebesar 0,133107582. Variabel manajemen laba mempunyai nilai minimum sebesar -0,100090, yang berarti bahwa perusahaan 
Kartika Widya Tri Dewanti dan I Gst Ngurah Agung Suaryana, Pengaruh...

tersebut melakukan manajemen laba dengan menurunkan labanya sebesar $10 \%$, sedangkan nilai maksimum sebesar 0,122070 yang berarti bahwa perusahaan tersebut melakukan manajemen laba dengan menaikkan labanya sebesar 12,21\%. Mean manajemen laba $-0,00070716$ yang memiliki arti bahwa perusahaan manufaktur yang terdaftar di Bursa Efek Indonesia tahun 2014-2016 melakukan manajemen laba dengan pola income decreasing rata-rata menurunkan labanya sebesar $0,07 \%$. Standar deviasi variabel manajemen laba sebesar 0,042342376.

Variabel PBV mempunyai nilai minimum sebesar 0,119690 memiliki arti bahwa perusahaan tersebut memiliki nilai PBV yang rendah dan belum bisa mensejahterahkan para pemegang saham perusahaannya, sedangkan nilai maksimum sebesar 2,716670 yang memiliki arti bahwa PBV yang tinggi, dapat dikatakan bahwa perusahaan telah mensejahterahkan para pemegang saham. Mean nilai perusahaan 1,02370873 dengan standar deviasi (simpangan baku) sebesar 0,640489976.

Uji asumsi klasik dilakukan untuk menguji dan mengetahui kelayakan model regresi yang digunakan dalam model ini.

Tabel 2. Hasil Uji Normalitas

\begin{tabular}{llll}
\hline No & Persamaan & N & Asymp. Sig \\
\hline 1 & $\mathrm{Z}=\mathrm{p}_{3} \mathrm{X}_{1}+\mathrm{p}_{4} \mathrm{X}_{2}+\mathrm{e}_{1}$ & 102 & 0,057 \\
2 & $\mathrm{Y}=\mathrm{p}_{1} \mathrm{X}_{1}+\mathrm{p}_{2} \mathrm{X}_{2}+\mathrm{p}_{5} \mathrm{Z}+\mathrm{e}_{2}$ & 102 & 0,131 \\
\hline \multicolumn{2}{l}{ Sumber :Data diolah, 2017} & &
\end{tabular}

Berdasarkan Tabel 2.dapat dilihat bahwa nilai Asymp. Sig dari kedua model persaman tersebut masing-masing bernilai 0,057 dan 0,131, dimana nilai tersebut 
ISSN: 2302-8556

E-Jurnal Akuntansi Universitas Udayana

Vol.24.3.September (2018): 1687-1708

lebih besar dari taraf signifikansi 0,05. Hal tersebut menunjukan kedua persamaan bersitribusi normal.

Tabel 3.

Hasil Uji Mutikolineeritas

\begin{tabular}{|c|c|c|c|c|}
\hline \multirow{2}{*}{ No } & \multirow{2}{*}{ Persamaan } & \multirow{2}{*}{ Variabel } & \multicolumn{2}{|c|}{ Collinearity Statistics } \\
\hline & & & Tollerance & VIF \\
\hline \multirow{3}{*}{1} & \multirow{3}{*}{$\mathrm{Z}=\mathrm{p}_{3} \mathrm{X}_{1}+\mathrm{p}_{4} \mathrm{X}_{2}+\mathrm{e}_{1}$} & KI & 0,673 & 1,487 \\
\hline & & KM & 0,673 & 1,487 \\
\hline & & KI & 0,651 & 1,535 \\
\hline \multirow[t]{2}{*}{2} & $\mathrm{Y}=\mathrm{p}_{1} \mathrm{X}_{1}+\mathrm{p}_{2} \mathrm{X}_{2}+\mathrm{p}_{5} \mathrm{Z}+\mathrm{e}_{2}$ & KM & 0,668 & 1,496 \\
\hline & & ML & 0,967 & 1,034 \\
\hline
\end{tabular}

Sumber : Data diolah, 2017

Berdasarkan Tabel 3. dapat dilihat bahwa nilai masing-masing variabel pada kedua model regresi tersebut memiliki nilai tolerance $>0,10$ dan memiliki nilai VIF $<10$ maka kesimpulannya adalah kedua model regresipenelitian ini bebas dari multikolinearitas.

\section{Tabel 4.}

Hasil Uji Autokorelasi

\begin{tabular}{cccc}
\hline o & Persamaan & $\begin{array}{c}\text { Durbin } \\
\text { Watson }\end{array}$ \\
\hline $\mathrm{Z}=\mathrm{p}_{3} \mathrm{X}_{1}+\mathrm{p}_{4} \mathrm{X}_{2}+\mathrm{e}_{1}$ & 02 & 2,266 \\
$\mathrm{Y}=\mathrm{p}_{1} \mathrm{X}_{1}+\mathrm{p}_{2} \mathrm{X}_{2}+\mathrm{p}_{5} \mathrm{Z}$ & & 02 & 1,896 \\
$+\mathrm{e}_{2}$ &
\end{tabular}

Nilai dw dari uji autokorelasi persamaan 1 berada diantara $d_{L}$ dan $4-d_{u}$ $(1,6376<2,266<2,2825)$. Sedangkan nilai $\mathrm{dw}$ dari uji autokorelasi persamaan 2 berada diantara $\mathrm{d}_{\mathrm{L}}$ dan $4-\mathrm{d}_{\mathrm{U}}(1,6174<1,896<2,2617)$. Hasil uji autokorelasi dengan pengujian Durbin Watson (DW) kedua persamaan tersebut berada pada daerah tidak terdapat autokorelasi sehingga model regresi yang digunakan tidak terdapat gejala autokorelasi. 
Tabel 5.

Hasil Uji Heteroskedastisitas

\begin{tabular}{cccc}
\hline No & Persamaan & Variabel & Signifikan \\
\hline \multirow{2}{*}{1} & $\mathrm{Z}=\mathrm{p}_{3} \mathrm{X}_{1}+\mathrm{p}_{4} \mathrm{X}_{2}+\mathrm{e}_{1}$ & $\mathrm{X}_{1}$ & 0,148 \\
& & $\mathrm{X}_{2}$ & 0,477 \\
& & $\mathrm{X}_{1}$ & 0,421 \\
2 & $\mathrm{Y}=\mathrm{p}_{1} \mathrm{X}_{1}+\mathrm{p}_{2} \mathrm{X}_{2}+\mathrm{p}_{5} \mathrm{Z}+\mathrm{e}_{2}$ & $\mathrm{X}_{2}$ & 0,541 \\
& & $\mathrm{Z}$ & 0,091 \\
\hline
\end{tabular}

Sumber : Data sekunder diolah, 2017

Berdasarkan Tabel 5, masing-masing variabel pada kedua model regresi memiliki nilai signifikansi $>0,05$. Jadi, model regresi dalam penelitian ini bebas dari gejala heterokedastsitas.

Penelitian ini menggunakan analisi jalur (path analysis), yang merupakan perluasan dari analisis regresi linier berganda untuk pengujian hubungan kausalitas antara lebih dari 1 variabel.

Model analisis tersebut dapat dinyatakan dalam bentuk persamaan, yaitu.

$$
\begin{aligned}
& \mathrm{Z}=\mathrm{p}_{3} \mathrm{X}_{1}+\mathrm{p}_{4} \mathrm{X}_{2}+\mathrm{e}_{1} \\
& \mathrm{Y}=\mathrm{p}_{1} \mathrm{X}_{1}+\mathrm{p}_{2} \mathrm{X}_{2}+\mathrm{p}_{5} \mathrm{Z}+\mathrm{e}_{2}
\end{aligned}
$$

Rangkuman hasil koefisen regresi yang distandarkan (standardize coefficient beta) disajikan pada table 6.

Tabel 6.

Ringkasan Koefisien Jalur Pengaruh Langsung

\begin{tabular}{ccccc}
\hline Regresi & $\begin{array}{c}\text { Koef. Reg } \\
\text { Standar }\end{array}$ & $\begin{array}{c}\text { Standar } \\
\text { Erorr }\end{array}$ & $\begin{array}{c}\text { Tingkat } \\
\text { Sig. }\end{array}$ & Ket \\
\hline $\mathrm{KI} \rightarrow$ PBV & $-0,469$ & 0,407 & 0,000 & Signifikan \\
$\mathrm{KM} \rightarrow \mathrm{PBV}$ & $-0,276$ & 0,520 & 0,012 & Signifikan \\
$\mathrm{KI} \rightarrow \mathrm{ML}$ & 0,218 & 0,407 & 0,000 & Tidak Signifikan \\
$\mathrm{KM} \rightarrow \mathrm{ML}$ & 0,096 & 0,520 & 0,012 & Tidak Signifikan \\
$\mathrm{ML} \rightarrow \mathrm{P} \mathrm{BV}$ & 0,372 & 1,358 & 0,000 & Signifikan \\
\hline
\end{tabular}

Sumber: Data diolah, 2017 


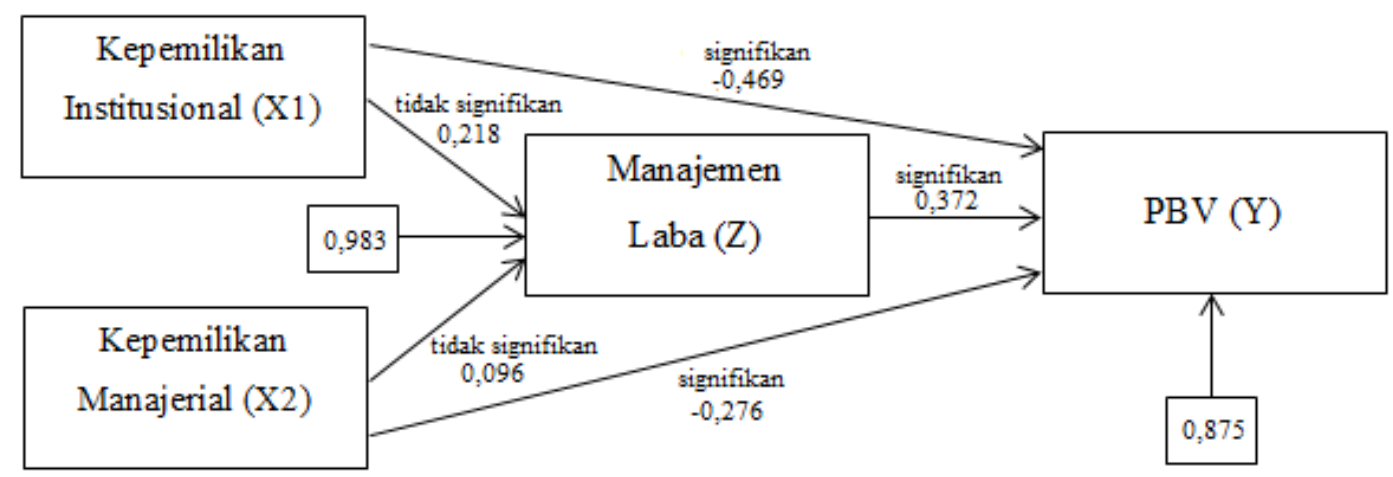

\section{Gambar 1. Diagram Hasil Analisis Jalur}

Uji hipotesis mediasi dilakukan dengan Uji Sobel (Sobel, 1982). Uji Sobel digunakan untuk menguji kekuatan pengaruh tidak langsung variabel kepemilikan institusional $\left(\mathrm{X}_{1}\right)$ terhadap nilai perusahaan $(\mathrm{Y})$ melalui variabel manajemen laba $(\mathrm{Z})$ dan pengaruh tidak langsung variabel kepemilikan manajerial $\left(\mathrm{X}_{2}\right)$ terhadap PBV $(\mathrm{Y})$ memalui variabel manajemen laba $(\mathrm{Z})$.

Standard error pengaruh tidak langsung (indirect effect) $\mathrm{S}_{\mathrm{ab}}$ dihitung sebagai berikut.

\section{Tabel 7.}

Standard Error Pengaruh Tidak Langsung

\begin{tabular}{cccccccccc}
\hline \multicolumn{1}{c}{ Variabel } & $\mathbf{A}$ & $\mathbf{B}$ & $\mathbf{a}^{\mathbf{2}}$ & $\mathbf{b}^{\mathbf{2}}$ & $\mathbf{S a}$ & $\mathbf{S b}$ & $\mathbf{S a}^{\mathbf{2}}$ & $\mathbf{S b}^{\mathbf{2}}$ & $\mathbf{S a b}$ \\
\hline $\mathrm{KI} \rightarrow \mathrm{ML} \rightarrow \mathrm{PBV}$ & 0,053 & 5,622 & 0,0028 & 31,607 & 0,030 & 1,358 & 0,0009 & 1,844 & 0,183 \\
$\mathrm{KM} \rightarrow \mathrm{ML} \rightarrow$ PBV & 0,031 & 5,622 & 0,0009 & 31,607 & 0,038 & 1,358 & 0,0014 & 1,844 & 0,218 \\
\hline \multicolumn{2}{r}{ Sumber: datadiolah, 2017} & & & & & & & &
\end{tabular}

Untuk menguji signifikansi pengaruh tidak langsung, maka nilai z pada koefisien ab dihitung dengan rumus

$$
\mathrm{z}=\frac{a b}{S a b}
$$




\section{Tabel 8.}

\section{Uji Signifikansi Pengaruh Tidak Langsung}

\begin{tabular}{lccccc}
\hline \multicolumn{1}{c}{ Variabel } & Ab & Sab & z-hitung & z-tabel & Keterangan \\
\hline $\mathrm{KI} \rightarrow \mathrm{ML} \rightarrow \mathrm{PBV}$ & 0,298 & 0,183 & 1,628 & 1,64 & Tidak terjadi pengaruh mediasi \\
$\mathrm{KM} \rightarrow \mathrm{ML} \rightarrow \mathrm{PBV}$ & 0,174 & 0,218 & 0,80 & 1,64 & Tidak terjadi pengaruh mediasi \\
\hline \multicolumn{2}{l}{ Sumber: data diolah, 2017}
\end{tabular}

Hasil dari rangkuman analisis jalur menunjukkan bahwa kepemilikan institusional berpengaruh negatif signifikan terhadap PBV. Hal ini menunjukkan bahwa semakin besar porsi kepemilikan institusional justru akan menurunkan PBV perusahaan.

Siregar (2008) mengemukakan bahwa 99\% struktur kepemilikan publik yang ada di Indonesia adalah kepemilikan terkonsentrasi yang terdiri dari kepemilikan langsung dan kepemilikan piramida. Kepemilikan piramida adalah kepemilikan tidak langsung baik melalui perusahaan publik maupun non-publik (Claessen et al., 2000). Masalah keagenan pokok yang terjadi di kepemilikan saham terkonsentrasi bukan lagi antara pemegang saham dengan manajemen, melainkan antara pemegang saham pengendali dan pemegang saham non-pengendali (La Porta et al., 1999). Pemilik akhir dalam struktur kepemilikan piramida sangat sulit diidentifikasi karena terdapat kepemilikan yang berlapis-lapis. Mekanisme kepemilikan piramida ini memungkinkan terjadinya ekspropriasi dalam perusahaan yaitu penggunaan kontrol untuk keuntungan pribadi atas distribusi kekayaan dari pihak lain.Hal tersebut akan menimbulkan masalah keagenen yang besar dan menyebabkan adanya sinyal negatif untuk pihak luar yang berdampak pada tidak tertariknya investor untuk menanamkan modalnya dan akan menyebabkan menurunnya PBV. 
ISSN: 2302-8556

E-Jurnal Akuntansi Universitas Udayana

Vol.24.3.September (2018): 1687-1708

Hasil dari rangkuman analisis jalur menunjukkan bahwa kepemilikan manajerial berpengaruh negatif pada PBV. Claessens et al., (1999) dalam Ulupui (2015) menyatakan bahwa lebih dari 50\% perusahaan di Indonesia dikontrol oleh keluarga. Campur tangan pemilik terhadap pengelolaan perusahaan yang besar, menyebabkan tidak dapat dipisahkannya kepemilikan oleh keluarga dan pengelolaannya. Chalmers et al., (2006) dan Core et al., (1999) dalam Ulupui dkk., (2015) menyatakan bahwa berbagai studi di Amerika banyak membahas tentang adanya kompensasi manajemen puncak yang digunakan bukan untuk meningkatkan nilai perusahaan, melainkan digunakan untuk kepentingan pribadi (self-interest) manajemen. Salah satunya yaitu ketika pemegang saham pengendali dengan bebas menempatkan kerabat atau keluarganyadi posisi pemimpin puncak(komisaris dan direksi) di perusahaan tersebut. Apabila hal tersebut terjadi, meskipun perlakuan secara formal yang diterima adalah menyerupaiprofessional manager yang lain, namun perbedaannya adalah mereka memiliki kekuatan yang lebih atas hak kontrolnya dan tidaklah mudah untuk diberhentikan karena adanya hubungan istimewa dengan pemegang saham pengendali. Fungsi monitoring tidak dapat berjalan dengan baik ketika pemegang saham pengendali memiliki hubungan istimewa dengan pihak manajemen.

Hasil dari rangkuman analisis jalur menunjukkan bahwakepemilikan institusional tidak berpengaruh pada manajemen laba. Adanya kepemilikan institusional tidak memiliki kemampuan untuk mengendalikan praktik manajemen 
Kartika Widya Tri Dewanti dan I Gst Ngurah Agung Suaryana, Pengaruh...

laba oleh pihak manajemen. Yang et al., (2009) menyatakan bahwa investor institusi lebih focus pada current earnings karena mereka beranggapan bahwa dirinya adalah pemilik sementara. Hasil penelian ini konsisten dengan konsep dari Porter yang menyatakan bahwa investor institusional merupakan pemilik yang lebih memfokuskan pada current earnings, yang mengakibatkan manajer terdorong melakukan tindakan untuk meningkatkan laba jangka pendek (Pranata dan Mas'ud 2003). Maka dari itu, adanya kepemilikan institusional belum tentu akan berdampak pada peningkatan proses pengawasan yang berpengaruh terhadap berkurangnya tindakan manajemen dalam melakukan manajemen laba.

Hasil dari rangkuman analisis jalur menunjukkan bahwa kepemilikan manajerial tidak berpengaruh terhadap manajemen laba. Dengan kata lain, adanya peningkatan jumlah kepemilikan manajerial, tidak menjamin berkurangnya praktik manajemen laba. Hal tersebut dapat terjadi karena kepemilikan saham manajerial di perusahaan tersebut masih tergolong kecil, yaitu dengan rata-rata kepemilikan saham hanya sebesar 6,9\%. Kenaikan jumlah saham manajerial yang tidak signifikan menyebabkan tidak ada pengaruhnya terhadap tindakan manajemen laba. Penelitian ini didukung oleh penelitian Gabrielsen et al., (1997) yang menyatakan struktur kepemilikan manajerial tidak mempengaruhi manajemen laba.

Hasil dari rangkuman analisis jalur yang dirangkum menunjukkan bahwa manajemen laba berpengaruh positif pada PBV. Hal ini menunjukkan bahwa pihak manajer memilih melakukan manajemen atas laba untuk meningkatnya PBV 
ISSN: 2302-8556

E-Jurnal Akuntansi Universitas Udayana

Vol.24.3.September (2018): 1687-1708

perusahaan. Agar. Salah satu tujuan pihak manajemen melakukan manajemen atas laba adalah untuk penghindaran atas pelanggaran perjanjian utang, karena sanksiyang berupa sulitnya memperoleh tambahan pinjaman akan diterima perusahaan ketika ia melanggar perjanjian tersebut(Maisyarah, 2016). Tindakan manajemen laba yang tidak mengganggu konsistensi arus kas merupakan sinyal positif yang direaksi sebagai good news oleh pasar. Hal tersebut tentunya berdampak pada peningkatan harga saham, yang akan berdampak juga pada peningkatan PBV.

Berdasar uji sobel menunjukkan bahwa z hitung $(1,628)$ lebih kecil dari z tabel $(1,64)$ sehingga $\mathrm{H}_{6}$ yang menyatakan bahwa manajemen laba merupakan variabel intervening pengaruh kepemilikan institusional terhadap PBV ditolak. Manajemen laba sendiri bukan merupakan variabel intervening karena variabel kepemilikan institusional tidak memiliki pengaruh signifikan terhadap manajemen laba.

Berdasar uji sobel menunjukkan bahwa z hitung $(0,80)$ lebih kecil dari z tabel $(1,64)$ sehingga $\mathrm{H}_{7}$ ditolak. Manajemen laba bukan merupakan variabel intervening karena variabel kepemilikan manajerial tidak berpengaruh terhadap manajemen laba.

\section{SIMPULAN}

Kesimpulan yang dapat diambil dari penelitian ini adalah kepemilikan institusional dan manajerial memiliki pengaruh negatif terhadap price book value (PBV), kepemilikan institusional dan kepemilikan manajerial tidak memiliki pengaruh terhadap manajemen laba, manajemen laba memiliki pengaruh positif terhadap PBV, 
Kartika Widya Tri Dewanti dan I Gst Ngurah Agung Suaryana, Pengaruh...

dan manajemen lababukan merupakan variabel intervening dalam pengaruh kepemilikan institusional maupun kepemilikan manajerial terhadap PBV.

Penelitian ini tentunya memiliki keterbatasan dan masih perlu untuk dikembangkan kembali untuk penelitan selanjutnya. Saran yang dapat diberikan adalah penelitian selanjutnya disarankan agarmengganti variabel manajemen laba dengan variabel yang lain dikarenakan dalam penelitian ini variabel tersebut tidak terbukti sebagai variabel intervening pengaruh struktur kepemilikan terhadap price book value (PBV), penelitian ini masih sebatas menggunakan perusahaan manufaktur yang terdaftar di BEI periode 2014-2016. Peneliti mengharapkan pada penelitian selajutnya untuk memperluas periode pengamatan atau bisa menggunakan perusahaan selain perusahaan manufaktur, pertimbangkan kembali penggunaan variabel nilai perusahaan yang dihitung dengan rasio.

\section{REFERENSI}

Alves, Sandra. 2012. Ownership Structure And Earnings Management Evidence From Portugal. Australian Accounting Business and Finance Journal. Vol. 6 (1).

Apriada, Kadek dan Made Sadha S. 2016. Pengaruh Struktur Kepemilikan Saham, Struktur Modal Dan Profitabilitas Pada Nilai Perusahaan. E-Jurnal Ekonomi dan Bisnis Universitas Udayana, 5(2), hal.201-218.

Brigham, Eugene dan Joel F Huston. 2001. Manajemen Keuangan II. Jakarta: Salemba Empat.

Chen, C. R. dan Steiner, T. L. (1999). Managerial Ownership and Agency Conflicts: A Nonliear Simultaneous Equation Analysis of Mana-gerial Ownership, Risk Taking. Debt Policy, and Dividend Policy. The Financial Review. Tallahassee, 34(1), pp.119-136. 
ISSN: 2302-8556

E-Jurnal Akuntansi Universitas Udayana

Vol.24.3.September (2018): 1687-1708

Claessens, Stijn; Simeon Djankov dan Larry H.P. Lang. 2000. The Separation of Ownership and Control in East Asia Corporations. Journal of Financial Economics, 58, pp.81-112.

Claessens, Stijn; Simeon Djankov; Joseph P.H Fan; dan Larry H.P. Lang. 2002. Disentangling the Incentive and Entrenchment Effects of Large Shareholdings. Journal of Finance, 57(6), pp.2741-2771.

Gabrielsen et al., 1997. Managerial Ownership, Information Content of Earnings, and Discreasionary Accruals in a Non-US Setting. Journal of Business Finance and Accounting, 29(7)(8), pp.967-988.

Hartanto, Dedy dan Yuterina Widi Nugrahanti. 2013. Pengaruh Kepemilikan dan Struktur Modal Terhadap Manajemen Laba. Jurnal Universitas Kristen Satya Wacana.

Islamiya, Maesa Kharisma Okta dan Lailatul Amanah. 2016. Pengaruh Kinerja Keuangan Dan Struktur Kepemilikan Terhadap Return Saham. Jurnal Ilmu dan Riset Akuntansi, 5(8), hal.1-16.

Jensen, M. and W. Meckling. 1976. Theory of The Firm Managerial Behavior Agency Cost, and Ownership Structure. Journal of Finance Economic.

Kadarusman. 2012. Pengaruh Kepemilikan Manajerial dan Kebijakan Hutang Terhadap Nilai Perusahaan. Jurnal Akuntansi Aktual, 1 (4).

La Porta, R.; F.I De Silanes and A. Shleifier. 1999. Corporate Ownership Around The World.

Maisyarah, Hijah; Maslichah dan M. Cholid Marwadi. 2016. Pengaruh Manajemen Laba dan Kinerja Keuangan Terhadap Nilai Perusahaan.Jurnal Ilmiah Riset Akuntansi, 6.

Pasaribu, Mirry Yuniyanti; Topowijono dan Sri Sulasmiyati. 2016. Pengaruh Struktur Modal, Struktur Kepemilikan Dan Profitabilitas Terhadap Nilai Perusahaan Pada Perusahaan Sektor Industri Dasar Dan Kimia Yang Terdaftar Di Bei Tahun 2011-2014. Jurnal Administrasi Bisnis (JAB), 35 (1). 
Kartika Widya Tri Dewanti dan I Gst Ngurah Agung Suaryana, Pengaruh...

Putri, Noviantara Dwi dan Etna Nur Yuyetta. 2013. Pengaruh Struktur Kepemilikan dan Kualitas audit Terhadap Manajemen Laba. Diponegoro Journal of Accounting, 2 (3).

Rasyid, Abdul. 2015. Effects of Ownership Structure, Capital Structure, Profitability And Company's Growth Towards Firm Value. International Journal of Business and Management Invention, 4 (4), pp.25-31.

Scott, William R. 2006. Financial Accounting Theory $4^{\text {th }}$. United Stated \& America: Pearson Prentice Hall.

Sobel, M. E. 1982. Asymptotic Confidence Intervals for Indirect Effects in Structural Equation Models. Social Science \& Medicine, 58 (8), pp.290-312.

Siallagan, Hamonangan dan M.Machfoedz. 2006. Mekanisme Corporate Governance, Kualitas Laba dan Nilai Perusahaan. Simposium Nasional Akuntansi IXPadang.

Siregar, Baldric. 2008. Ekspropriasi Pemegang Saham Minoritas dalam Struktur Kepemilikan Ultimat. Simposium Akuntansi XI. Universitas Tanjung Pura Pontianak.

Ulupui, I Gusti Ketut Agung; Sidharta Utama dan Kresnohadi A.K. 2015. Pengaruh Kepemilikan Keluarga, Kedekatan Direksi \& Komisaris Dengan Pemilik Pengendali Terhadap Kompensasi Direksi \& Komisaris Perusahaan Di Pasar Modal Indonesia. Jurnal Organisasi dan Manajemen, 11 (1), pp.62-74.

Watts, R.L dan J.L. Zimmerman. 1986. Positive Accounting Theory. New Jersey: Prentice Hall.

Yang, W. S.; S. C. Loo and Shamser. (2009). The Effect of Board Structure and Institutional Ownership Structure on Earnings Manage-ment. International Journal of Economics and Management, 3(2), pp.332-353. 